\begin{tabular}{c} 
Volume and Issues Obtainable at Center for Sustainability Research and Consultancy \\
Journal of Business and Social Review in Emerging Economies \\
ISSN: 2519-089X (E): 2519-0326 \\
Volume 6: No. 2, 2020 \\
CSRᄃ \\
Journal homepage: www.publishing.globalcsrc.org/jbsee \\
\hline
\end{tabular}

\title{
The Post-Corona World and International Political Landscape: Emerging Challenges
}

\author{
${ }^{1}$ Attiq-ur-Rehman, ${ }^{2}$ Shahid Hussain Bukhari, ${ }^{3}$ Syed Mussawar Hussain Bukhari \\ ${ }^{1}$ Assistant Professor, Department of International Relations, National University of Modern \\ Languages (NUML), Islamabad, Pakistan arehman@numl.edu.pk \\ ${ }^{2}$ Associate Professor, Department of International Relations, Bahauddin Zakariya University, \\ Multan, Pakistan \\ ${ }^{3}$ Associate Professor, Department of Political Science, The Islamia University of Bahawalpur, \\ Bahawalpur, Pakistan
}

\begin{tabular}{l} 
ARTICLE DETAILS \\
\hline History \\
Revised format: April 2020 \\
Available Online: May 2020 \\
\hline
\end{tabular}

\section{Keywords}

Covid-19, Corona Epidemic,

International System, World

Politics

JEL Classification:

H57, L15, O4, O47, F43

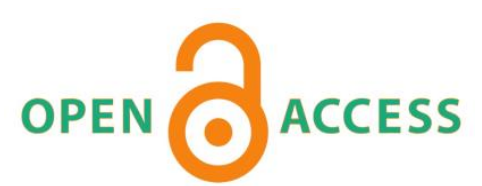

\section{ABSTRACT}

The outbreak of the global pandemic and its global outreach has challenged and shocked the international community. It has paralyzed the nations through upending the mainstream social, political, and economic activities of nations. The Covid-19 related restriction further suspended the normal affairs of states under an international environment of a health emergency. The pandemic crisis has clearly communicated to the international community that the digital world has arrived because the dependency on information technology has raised the significance of hi-tech communication networks in the world. This global crisis has endangered international society and the nations are struggling against the Covid-19 viral disease. No doubt, the whole international system has gradually learned to survive in the health crisis and the leaders from around the world are thinking of resuming normalization, but the actual question linked to the global governance in the postcorona world is unanswered. This pandemic year has raised the need for a serious conversation on the future of global political order because the Covid-19 has undermined the conventional wisdom attached to the crisis management mechanism of states. In short, the heating debates of the post-corona international political environment have generated a process of de-globalization and the international community is approaching a new world based on new realities. Therefore, this study is an endeavor to estimate the probable future scenario which will become an undeniable reality in the post-corona world.

(C) 2020 The authors, under a Creative Commons Attribution-

NonCommercial 4.0

Corresponding author's email address: shahidpolsc@ yahoo.com

Recommended citation: Attiq-ur-Rehman, Bukhari, S.H., \& Bukhari, M.H. (2020). The Post-Corona World and International Political Landscape: Emerging Prospects and Challenges. Journal of Business and Social Review in Emerging Economies, 6(2), 453-461

DOI: $10.26710 /$ jbsee.v6i2.1154 


\section{Introduction}

The Covid-19 virus and its devastating impacts on the world have undermined the conventional structure of the international system. The world prior to the novel-corona virus has become a part of history because the outbreak of the global pandemic has brought an unimaginable wave of crisis and left worse impacts on the social, political, and economic infrastructures of nations. An overwhelming wave of the global crisis has changed the entire international system by upending global human activities. Further worse impacts of the pandemic have disturbed regular business activities and launched an international wave of a financial crisis. The social activities of the nations have affected as well due to a gigantic inundation of human killings along with affected political personalities of different countries. At the political level, the suspension of legislative activities and launching of broader relief programs along with postponing of elections in various countries has shocked the nations. (Todd Landman and Luca Di Gennaro Splendore, 2020, pp. 2-3) Moreover, the deaths of political personalities and cancellation or rescheduling of major political events disturbed the governments. The spread of the virus and the rising number of infected cases raised the social anxiety and normal cultural attributes of the nations suspended for an indefinite period. In addition to political and social problems, a prodigious wave of economic crisis covered the whole international system without sparing a single state. In short, the spread of pandemic at the global level affected the nations in different ways and forced the countries to stop their normal life patterns. The states from different parts of the world have changed their normal conventional ways of working and living. The initial cases of this viral disease were reported from the Chinese city of Wuhan and the World Health Organization (WHO) officially called it the COVID-19. (WHO Timeline-COVID19, 2020) The outbreak of new coronavirus from Wuhan dramatically reached other nations and it became a grave threat to the entire world.

This is evident that the outbreak of the novel-corona virus has shocked mankind and the world has accepted a global wave of crisis. While surviving under an indefinite period of a global health emergency, the governments are trying to invest their potential capacities in protecting their citizens because the devastating transnational effects of this viral disease has paralyzed the nations. In order to counter the spread of diseases around the globe, an updated approach of concentrated efforts cemented in coordinated interaction between states is needed. In this context, the outbreak of Coronavirus has initiated a new debate in the international system and people around the world mainly consisting of public health officials, leading policymakers, academic researchers, and security pundits have started exploring the probable future of world order in the post-Corona scenario. This pandemic outbreak has launched an inclusive debate on various topics mainly covering the social, political, and economic fields. (Mishra, 2020, p. 22) No matter how the Coronavirus erupted and engulfed the whole international system without sparing any nation, its impact on the world cannot simply be ignored. A wide range of consequences after the elimination of Corona episode from the world will affect living standards of people parallel to disrupting the financial markets and national governments. Moreover, a permanent shift in the political, social, and economic features of the world will create a new future of the world in which the leading academic and political circles of the international community will witness a different world. (Mishra, 2020)

The spread of pandemic at the global level has engulfed the whole international system which will have broader implications for all states because the outbreak of viral disease has shown its potential of redefining the social, political, economic, and cultural affairs of the states in the international system. The aftermaths of the corona episode will alter the conventional wisdom attached to the regular affairs of states and it will demand the political authorities of the nations to alter the traditional ways of managing their major state affairs. Therefore, the central theme of the paper revolves around the future of world politics in the post-corona international system in which the world of new realities after the Covid-19 episode will fabricate a different global order. The new world will bring a lot of opportunities coupled with a long list of social, economic, and political challenges. Now, the nation-governments are forced to rethink their positions in the regional and global environment by redefining their strategic priorities. Furthermore, the states are now forced to transform their mainstream economic and social infrastructures 
in cyberspace by adopting digital techniques. The future of e-commerce is an inevitable reality that will require all the states to increase their dependency on information technology. In this way, this paper is an endeavor to provide an idea of various probable future scenarios in international politics.

\section{The Covid-19 Epidemic: A Global Crisis}

In view of the situation cited above, the recent phase of Coronavirus and its dramatic spread in the world can easily be examined by estimating the widespread human sufferings of the different regions. This viral atmosphere across the borders, no doubt, is demanding an adequate mechanism for treating the individual patients. But the prevention of its further spread within different communities has become a difficult task for the international community. The Coronavirus Disease started its spread in 2019 commonly known as COVID-19. This infectious disease causing severe acute respiratory syndrome has become a global issue, and its domino effects are rapidly making various communities of different countries more vulnerable. The helpless leaders from around the world are trying to invest their efforts for taking precautionary measures coupled with adopting protective policies to secure their citizens. (Snowden, 2020, pp. ix-xii) The pandemic COVID-19 was first identified in China (Wuhan) at the end of 2019 and gradually reached an alarming level by causing thousands of deaths in different countries while leaving hundreds of thousands affected. A minor level of recoveries besides the skyrocketing level of Corona cases reported from different counties.

The Covid-19 has become a global issue because it has placed the entire international system under lockdown and the states from every region are compelled to adopt various phases of countywide lockdowns. Under a broader vision of non-traditional security threats, the COVID-19 can be studied as an important event in the history of mankind which will leave remarkable impacts on the international system. Apart from countless reports prepared by various health organizations, the political impacts of Coronavirus cannot be marginalized. This disease has affected mainstream social infrastructures, political systems, and conventional legislative activities of affected states. The economic crisis caused by this pandemic syndrome apart from canceled and postponed national and international events from around the globe multiplied the impacts of COVID-19. (Snowden, 2020) Additionally, multiple deaths of politicians and the rescheduling of the electoral process of various states due to the fear of the spread of Coronavirus augmented the ongoing panic in the people. Beyond offsetting the traditional social and political infrastructures of the states, this epidemic illness disturbed the inter-state relations by negatively affecting a worldwide culture of trade and travel. No doubt, like other epidemic diseases, the Corona plague will also be controlled sooner or later but its impacts on the international system will reshape the global order. In other words, the end of Coronavirus from the world will provide greater relief to mankind from natural disasters, but it will change the course of world history in different ways. In order to comprehend the probable future of the international system in the post-Corona scenario, the following situations will likely shape the future of the world. (Moulay Driss El Maarouf et al, 2020, pp. 2-4)

Witnessing from history, the global scale crisis could idealistically be overcome by enhancing cooperation between states. But the coronavirus incident has raised various points of disagreements between great powers instead of creating an international unified response structured on a global alliance. It has added another layer of strategic politics between states because the efforts to identify the causes and the sources of origin of this virus, a new blame-game is going to start between states. In view of the aforementioned circumstances, an international environment of extended anarchy will prevail in world politics. States will try to relay on their own economic capacities to prepare themselves against future crises. On one hand, the national leaders will try to cooperate with their counterparts of other regions for the formulation of a more coordinated and less confrontational approach. On the other hand, the leading state authorities will be reluctant in relaying the cooperation of other countries. Consequently, the policymakers will prefer to adopt a policy of self-reliance which will not only empower the national infrastructure of the states but it will also reduce the chances of depending on other governments. It will further let the security architectures of the nations to achieve strategic autonomy in defense matters. (Balasubramanian, 2020, p. 94) Moreover, a shattered idea of global economic governance will hamper the existing economic systems 
of states and it will make states more vulnerable to a financial crisis. It will be a retreat from a growing culture of the global economy which will further structure new economic directions for the nations by complicating the international anarchical environment.

\section{Conceptual Understanding}

The novel-corona virus and its spread in the world have become a turning point of world history because the outbreak of pandemic from China and then its global outreach has shaken foundations of the international system. Analogous to the history of international politics, an archival record of the world witnessed a number of events which left significant impacts on the global society. The outbreak of wars, the signing of treaties, creating alliances, and the outbreak of epidemic diseases proved to be the turning points of world history. Besides other forces changing the conventional political patterns of the world, the spread of infectious diseases affected the populous centers of the world without respecting the territorial borders. The outbreak of deadly pandemics in the forms of HIV/AIDS, Flue, Cholera, and black death along with the plagues of Justinian and Antonine choked the international society. (Outbreak: 10 of the Worst Pandemics in History, 2020) An exceptional combination of naturally occurring and intentionally spreading epidemic diseases under the broader rubric of biological threats usually causes a large number of human sufferings. The most populous nations facing an unmeasurable strength of deaths and disabilities became vulnerable before the spread of pandemic illnesses. An uncontrollable level of such sicknesses globally made the nations less secured and more defenseless. With the passage of time, an escape from the threats of such biological catastrophes became an impossible task for the nations.

The modern debates of international society initiated after the decades-long American-Soviet hostility under the Cold War period. The end of the Cold War constructed an international Soviet-less system that generated a debate of the twenty-first century around the globe. The arrival of the twenty-first century was considered to be a turning point of world history because the beginning of the new millennium was treated as an important event that can change the nature of international society. Parallel to the advent of the twenty-first century, the debate of globalization spread across the world. The notion of a globalized world introduced various changes in the world by upgrading the roots of the international system. It revolutionized the lives of states through bringing a system of growing economic interdependence, bring the culture and population closer, beginning a free flow of information, people, and investment, and creating a digital world. (Ritzer, 2010, p. 3)

The world full of various globalizing forces based on the free flow of goods has started losing its relevance to the contemporary global society because the borderless world has been challenged by the Covid-19. The basis of free transformation of goods, money, information, and people has become a matter of less relevance to the world before the pandemic crisis. Initially emerging from China, the viral disease has reached every corner of the world and forced the decision-makers to breakdown the supply of goods in inter-state relations. The suspension of supplies has not only decreased the supply of essential products, but it has downed the imports-exports rates worldwide. As a result, it has raised the importance of decades-old sovereign state system functioning beyond the forces of globalization. The significance of national interest has been increased globally and the state governments have redefined their priorities. The pursuit of national interest first is intended to become a vibrant trend like President Trump's America First policy. (Anton, 2019) President Trump's doctrine of American First has already announced the notion of putting the national interest ahead of global interest-based on universal values.

In extension to the American deviation from its global role of addressing international problems, the USled global war on terror has become an outdated pattern in the world. Washington's commitment to creating the world free of terrorism parallel to creating an international political order of Americansupporting unipolar designs as the result of the tragic event of 9/11 has begun to lose its value in the world. The catastrophic effects of viral disease in the world has made international cooperation for addressing the common threat of terrorism a fragile domain of the global society. (Goldenberg, 2020) The arrival of the pandemic in the countries located in different regions has vanished the role of global 
counter-terror alliance and the political authorities of the nations have prioritized the Covid-19 more important than terrorism. In other words, the spread of the novel-corona virus in the world has diminished the role of US-sponsored war against terrorism and forced the governments to protect their citizens from a deadly disease. (Khalil, 2020) The power of the sovereign state system has started to grow and the stategovernments have turned towards the crisis of global pandemic instead of solely carrying the counterterror campaigns. The United States even has realized the need to put greater emphasis on transitional security threats beyond the threats of terrorism.

By looking to the world beyond terrorism has let Washington consider the role of non-traditional security threats including the threats pandemic. Besides the United States, the leaders of the developed world have started thinking of a world of non-traditional security threats based on transitional pandemic issues. In contrast to the cross-border issue of terrorism and global warming, the international community has embraced the threats of the global pandemic. (Monshipouri, 2020) The rise of non-traditional security threats has proved that the age of human security has arrived and the custodians of peace and security should take care of humans encircled by territorial borders. The security of territorial borders has partially been replaced by cross-border security threats. In short, the strategic landscape of the world has been changed and the traditional concepts of the post-twenty-first century, post-globalization, and post 9/11 have been replaced by the post-corona world. The world of post-corona management shifted the focus of political authorities from traditional to non-traditional security threats. From the perspective of international politics, the global health emergency under the Covid-19 has added a new chapter in the history of mankind by changing the nature of global politics.

\section{Change in Global Politics}

The global pandemic is intended to magnify the contemporary geopolitical foundations of the international system because a race to find an appropriate method of containing the spillover effects of the pandemic has inaugurated a new race between great powers. The leaders of the developed nations are struggling to introduce various methods of controlling the devastating impacts of this viral disease. Another way layer of politics has been generated with the struggle of identifying the reasons for its spread across the globe. The efforts to identify the origin and source of coronavirus raised several speculations in which will alter the contemporary patterns of great power politics. So, the effects of the pandemic have effected the ongoing basis of international relations because the rising diplomatic tensions equivalent to declining economic situations are leaving significant impacts on the inter-state hostilities. Observing the contemporary situation, the leaders of different countries have begun to accusing other nations of not effectively containing the spread of the virus. Another group of nations has started blaming their rivals for not efficiently participating in global counter-corona efforts. In addition to declining economic conditions, the scarcity of food, the shortage of medical equipment, lack of adequate medical infrastructure, and the inefficient health standards have left worse impacts on the balance of power politics in different regions. In this way, the rising tensions over the issues of trade and investment along with the supply of medicines and medical equipment will redefine the future of world politics. The new political designs between great powers will change the nature of the balance of power politics while inaugurating a competition between states over health issues.

The post-Corona world is probable to witness a new international system where the great power competition will face an altered version of power politics. Presently, the existing confrontational designs between China and the US have taken a new turn in which the American state officials are blaming Beijing as the culprit of spreading the virus from Wuhan. In return, Beijing has started mentioning the speculations that the virus has been used by the US military as a weapon against China. The blame-game between Beijing and Washington is not likely to vanish in the near future. In fact, an intense hostility between two superpowers will provide sufficient space for other power or it will let other power to take benefit of Sino-US aggression. The most probable future of the world will allow both Chinese and American governments to start formulating their alliances in the different regions under a global bipolar system. This polarization based on Chinese-American values will create a new world while effecting the 
political designs of different regions. No doubt, the novel-corona virus has halted global politics by making the governments helpless during the international health crisis, but still the great powers are continued to secure their dominating positions in the world. With respect to the ongoing blame-game between Beijing and Washington, more conspiracy theories are likely to add further dimensions in the Sino-US confrontation. In other words, the debate on defining the Coronavirus as a natural disaster or a man-made disaster will leave a significant impact on the global political order. In response to the emerging features of the new world, the national capitals from different regions will try to redefine their position while adjusting their geostrategic interest in a new world. In this way, an updated version of global politics will try to change the traditional concepts of inflexible rivals, potential competitors equivalent to modifying the concepts of cooperative partners and trustworthy allies.

The above mentioned scenario suggests the beginning of corona-management politics and the contemporary hostilities between states will be reshaped in the post-corona world. No doubt, the coronacontrolling efforts will inaugurate a new domain in the global politics, but the multilateral frameworks at regional and international levels will create different state alliances for cooperating for preventing the repetition of future health contingencies. As the pandemic affected the social and economic infrastructures of states, all the states are equally vulnerable and the governments were failed to manage an escape. Therefore, there are chances of more cordial relations between states because the universal problem demands maximum cooperation from every nation.

\section{A New Economic Competition}

The new economic environment will introduce a digital transformation in the business sector under the broader framework of new globalization which will be capable of generating a new competition of open markets. The novel-corona virus has pushed the whole international system towards a new economic system and changed the nature of international trade and investment. In this way, a process of deglobalization will be replaced by an updated framework of globalization which could be treated as newglobalization in which the multinational companies will spread their business across the globe instead of focusing selected areas. The same structure will be followed by the various government because the politics' new economy will be updated under a changed pattern of global geopolitics. (James, 2001, p. 18) The outbreak of Coronavirus form China and its dramatic spread in the world has traumatized the financial systems of states and broadly resulted in the collapse of the global economic system in which the leading economists of different countries are failed to protect their nations. COVID-19, the major event of the leap year, has brought a major economic crisis in the world by upsetting the performance of national and international organizations. In this way, the collapse of the international financial market sabotaged the consistent trade patterns of stock exchanges around the globe. The disappointing economic surveys of even economically developed and technologically advanced states have alarmed the whole world. It further has diminished the chances of global investors due to the reduction of chances of international trade and travel. The upsetting western economic circles are forced to rise their anti-Chinese positions while calling the post-Corona world as a new world in which China will not be an economic power. Now, the end of the Chinese era will provide sufficient space to the other powers or it will compel Beijing to recover its economic rise again. No doubt, China is the first victim of Coronavirus but it is trying to lead the world in overcoming this pandemic plague. Besides fracturing the concept of the Chinese economic rise, the world of new economic challenges will change the role of multinational organizations parallel to altering the performance of business communities in the world. (Mathew J. Burrows and Peter Engelke, 2020) Moreover, the spread of this disease in the world has stopped the multinational trading companies from investing in geographically selected areas.

In response to an overwhelming wave of the global health crisis, the utility of information technology has been increased. The people from around the world preferred to rely on digital communication networks which increased the public reliance on cyberspace. As a result, securing the flow of data and information across the borders has become a fundamental concern of the political leaders. The creation of a digital world based on various communication networks is no more a dream because the pandemic launched a concept of a physically distanced society. A common trend as the result of the global pandemic has 
reduced the significance of the working environment in the office because the nations are compelled to rely on wider networks of information technology. The killing of office culture has changed the nature of professional engagements across the globe and people have learned to perform their professional duties through digital networks. (Marr, 2020) Even the government institutions, financial organizations, and major public service centers have transformed their infrastructures on cyberspace which has increased the utility of digital networks in the world. Now, an adequate awareness of the cyberspace and the use of online trading trends have become an essential need of every individual. The increasing dependency on cyber has increased the opportunities for the business community because the corporate sector will have the only option of converting their businesses online and they will be able to facilitate the consumers in an effective way. The emergence of digital networks across the globe will require governments to rethink their traditional ways of managing societies.

\section{Social Change}

A number of short term emergency measures due to the global health crisis have temporarily suspended the basic human rights. The government restrictions on the rights of free movements threatened the notion of civil liberties during the pandemic, and this era of public health emergency forced the leaders to take essential legislative measures for preventing the spread of viral disease. As a result, the scarifying of fundamental human rights created a number of policy responses from the governments in the form of implementing lockdowns and socially distancing. In this way, a wave of global human rights crises spread parallel to the spread of the global health crisis. (Human Rights Watch, 2020) The situation became worse with the termination of basic human rights and the implementation of nationwide lockdowns along with the enactment of a socially distancing policy. Governments from around the globe preferred to fulfill their obligations to protect the citizens against the serious public health threats. (Human Rights Watch, 2020)

Moreover, the disturbance at the societal level started with panic among people in the form of a shortage of supplies of medical equipment and major food items. The empty shelves of supermarkets were the first tangible impact of viral disease because the fear of shortage of supplies of essential commodities resulted in an environment of panic-buying. Later on, the closure of national borders added fuel into the fire by disrupting the transportation of essential goods between countries. The suspension of various harvesting season further raised the social unrest in nearly every country, and people attached to the agricultural industry started facing massive unemployment. The problem of unemployment became serious with the closure of many companies and employees started facing the issues of temporary and permanent restrictions on their jobs. In this way, the combination of the food crisis and employment disaster increased the social strife in many countries. The states from developing and developed parts of the world are equally affected in the global wave of a health crisis.

The wounded societal frameworks of the nations will be changed in the post-corona environment and the protection of social and labor rights will be the demands of the new system. The change in the nature of the global working environment and the rise of networks for the corporate sector will create a world of extended cyberspace in which the dependency on the internet has the only viable option. The increase of online work will demand an increased literacy rate along with the prevalence of multiple high-speed information communication networks in the world. The post-corona cities will uphold the idea of social distance by maintaining a socially distanced and digitally connected society where the citizen will be closely connected through the hi-tech communication networks. Furthermore, the end of the pandemic will raise the need for a new society based on the low rate of traveling and reducing the culture of socially no-touching. Keeping social distance will reshape various cultural norms by leaving the profound impacts of the global culture of touching through shaking hands. In this way, an improved global culture of updated social norms will create a new societal framework of reduced close personal contacts. (Fetters, 2020)

\section{A Changed Nature of International System}

The concept of globalization has been badly affected as the result of COVID-19 because this universal 
problem has shaken the foundations of the international system. People from different corners of the world have started visualizing the world from a different angle in which the features of a globalized world have started losing their relevance to the international system. Even the political leaders are reluctant in sharing of their global agendas while opposing widespread opportunities for trade and travel in the world. Some analytical circles of the world agreed to call this pandemic a global bug and it will reshape the structure of inter-state interaction. (Yoon, 2020) The leading state authorities will try to prefer the protection of their borders as an adequate measure to defend their people. Another group of political leaders will try to support the concept of nationalism by defending their domestic systems in order to manage the reoccurrence of any crisis in the future. It is more appropriate to say, the politics of the epidemic will marginalize the role of globalization by emphasizing a system of state-government over the people. In this system, the citizens will look at their leaders and consider them the viable sources of protecting them from crises instead of relying on foreign funding. Moreover, the traditional governing apparatuses of states while living under self-imposed isolation will be reluctant to formulating their trade connection with other nations. Consequently, a world of less-opened order, less-free travel, and lesspleasant transnational economic values will introduce a system of retreat from globalization.

\section{Conclusion}

An environment of various universal changes as the result of Corona-related restrictions has inadvertently changed the nature of the international system. The suspension of normal activities of various nations has complicated the global political, social, and economic affairs by paralyzing the normal lives of states. In the future, a number of modern ways to manage health issues will emerge from different parts of the world because the Covid-19 has engaged the global society in the health sector. All the countries have realized that the outbreak of the viral disease in the world has revealed the weak health systems of the states. All the states are equally vulnerable before the global health crisis and there is a dire need for securing the future of the nations by efficiently protecting the citizens from transnational health issues. The bio-surveillance codes will regulate the social movements of the people for the purpose of monitoring the health emerging health issues in society. With the help of this system, the governments will be able to reduce the chances of repetition of a global pandemic in the world. At the global level, a number of initiatives in the form of an international health authentication system or the issuing of an immunity travel document will become an apparent trend in the inter-state travel because the state government will emphasize the protection of their citizens more than physically defense of territorial borders. The sharing of health data in the inter-state relations will become essential elements of foreign relations because the national government will prefer to defend their borders from the threats of epidemic disease.

Keeping in view the future of inter-state relations, a more cooperative and less hostile approach will serve the interest of all states. A unified approach structured on a closely coordinated and diligently harmonizing manner will be more effective rather than carrying a traditional method of addressing global problems. In this way, the international society will experience a new system structured on various health initiatives at national, regional, and international levels. The leading legislative authorities of various nations need to take essential policy measures in the domestic system for public awareness. Because during the public health crisis, urging the people is more productive than enforcing the people for the persuasion of a particular policy. In addition to improving the domestic societal systems, the state governments are required to overhaul the conventional patterns of maintaining inter-state relations. The mainstream foreign relations between states will prioritize their cooperation for upholding public health standards. In this way, the cooperation to address common health issues will encourage the leaders to formulate different regional alliances to overcome future health contingencies. A united regional nexus of different states will contain substantial potential to empower a global campaign to diminish the probabilities of a future health crisis. Witnessing from history, the international community has experienced a number of initiatives to address the common cause by cooperating with each other.

The abovementioned scenario suggests the need for taking various adequate steps to secure the future of a healthy human race. A unique combination of unilateral, bilateral, and multilateral measures can assist the international community in achieving a corona-free world. An effective pandemic management system 
will enable the states to structure a safe and secure system for the coming generations.

\section{References}

Anton, M. (2019, April 20). An Insider Explains the President's Foreign Policy. Foreign Policy. Retrieved May 16, 2020, from https://foreignpolicy.com/2019/04/20/the-trump-doctrine-big-think-america-first-nationalism/

Balasubramanian, M. (2020). Covid-19: The New Age Pandemic. Chennai: Notion Press.

Fetters, A. (2020, March 10). When Keeping Your Distance is the Best Way to Show You Care. Retrieved April 30, 2020, from The Atlantic: https://www.theatlantic.com/family/archive/2020/03/how-coronavirus-causedhug-and-handshake-hiatus/607762/

Goldenberg, I. (2020, March 19). 9/11 Swallowed U.S Foreign Policy. Don't Let the Coronavirus Do the Same Thing. The Washington Post. Retrieved April 26, 2020, from https://www.washingtonpost.com/outlook/2020/03/19/trump-china-bush-iraq/

Human Rights Watch. (2020, April 14). Covid-19 Offers Chance to Address Human Rights Concerns. Retrieved April 30, 2020, from Human Rights Watch: https://www.hrw.org/news/2020/04/14/covid-19-offers-chanceaddress-human-rights-concerns

Human Rights Watch. (2020, March 19). Human Rights Dimensions of Covid-19 Response. Retrieved May 15, 2020, from Human Rights Watch: https://www.hrw.org/news/2020/03/19/human-rights-dimensions-covid19-response

James, H. (2001). The End of Globalization: Lessons from the Great Depression. Massachusetts: Harvard University Press.

Khalil, L. (2020, May 01). Covid-19 and America's Counter Terrorism Response. Retrieved May 16, 2020, from War on the Rocks: https://warontherocks.com/2020/05/covid-19-and-americas-counter-terrorism-response/

Marr, B. (2020, April 03). 9 Future Predictions for a Post-Coronavirus World. Retrieved April 30, 2020, from

Forbes: https://www.forbes.com/sites/bernardmarr/2020/04/03/9-future-predictions-for-a-post-coronavirusworld/\#4f57f3d15410

Mathew J. Burrows and Peter Engelke. (2020, April 23). What World Post-Covid-19? Three Scenarios. Retrieved April 30, 2020, from Atlantic Coucncil: https://www.atlanticcouncil.org/in-depth-researchreports/report/what-world-post-covid-19-three-scenarios/

Mishra, S. (2020). The Post-Pandemic World Order: Nine Pointer. New York: Indra Str Papers.

Monshipouri, M. (2020, April 20). The Post-Coronavirus World Order. Retrieved April 30, 2020, from Modern Diplomacy: https://moderndiplomacy.eu/2020/04/20/the-post-coronavirus-world-order/

Moulay Driss El Maarouf et al. (2020, April). Covid-19: A Critical Ontology of the Present. Education Philosophy and Theory, 52(07).

Outbreak: 10 of the Worst Pandemics in History. (2020). Retrieved May 27, 2020, from MPH Online: https://www.mphonline.org/worst-pandemics-in-history

Ritzer, G. (2010). Globalization: A Basic Text. West Sussex: Wiley-Blackwell.

Snowden, F. M. (2020). Epidemics and Society: From the Black Death to the Present. New Haven: Yale University Press.

Todd Landman and Luca Di Gennaro Splendore. (2020). Pandemic Democracy: Elections and Covid-19,. Journal of Risk Research, 23, No. 04(04).

WHO Timeline-COVID-19. (2020, April 27). Retrieved May 15, 2020, from World Health Organization: https://www.who.int/news-room/detail/27-04-2020-who-timeline---covid-19

Yoon, E. (2020, May 26). 3 Behavioral Trends That Will Reshape Out Post-Covid World. Harvar Business Review. Retrieved May 27, 2020, from https://hbr.org/2020/05/3-behavioral-trends-that-will-reshape-our-postcovid-world 